University of Nebraska - Lincoln

DigitalCommons@University of Nebraska - Lincoln

USDA National Wildlife Research Center - Staff

Publications
U.S. Department of Agriculture: Animal and Plant Health Inspection Service

January 2005

\title{
The Geographically Contiguous and Expanding Coastal Range of the Northern Curlytail Lizard (Leiocephalus carinatus armouri ) in Florida
}

Walter E. Meshaka Jr.

State Museum of Pennsylvania

Henry T. Smith

Florida Department of Environmental Protection, Florida Atlantic University

Richard M. Engeman

USDA-APHIS-Wildlife Services, s_r100@yahoo.com

Christopher L. Dean

Florida Department of Environmental Protection

Jon A. Moore

Florida Atlantic University

See next page for additional authors

Follow this and additional works at: https://digitalcommons.unl.edu/icwdm_usdanwrc

Part of the Environmental Sciences Commons

Meshaka, Walter E. Jr.; Smith, Henry T.; Engeman, Richard M.; Dean, Christopher L.; Moore, Jon A.; and O'Brien, William E., "The Geographically Contiguous and Expanding Coastal Range of the Northern Curlytail Lizard (Leiocephalus carinatus armouri ) in Florida" (2005). USDA National Wildlife Research Center - Staff Publications. 24.

https://digitalcommons.unl.edu/icwdm_usdanwrc/24

This Article is brought to you for free and open access by the U.S. Department of Agriculture: Animal and Plant Health Inspection Service at DigitalCommons@University of Nebraska - Lincoln. It has been accepted for inclusion in USDA National Wildlife Research Center - Staff Publications by an authorized administrator of DigitalCommons@University of Nebraska - Lincoln. 
Authors

Walter E. Meshaka Jr., Henry T. Smith, Richard M. Engeman, Christopher L. Dean, Jon A. Moore, and William E. O'Brien 


\title{
The Geographically Contiguous and Expanding Coastal Range of the Northern Curlytail Lizard (Leiocephalus carinatus armouri) in Florida
}

\author{
Walter E. Meshaka, Jr. ${ }^{1, *}$, Henry T. Smith ${ }^{2,5}$, Richard M. Engeman ${ }^{3}$, \\ Christopher L. Dean ${ }^{4}$, Jon A. Moore ${ }^{5}$, and William E. O’Brien ${ }^{5}$
}

\begin{abstract}
We surveyed for the presence of the Northern Curlytail Lizard, Leiocephalus carinatus armouri, from Port Salerno, Martin County, FL, northward to the Indian River-Brevard county line to determine the extent to which this species occurs along the Florida East Coast. The geographic range of L. c. armouri appears to be uninterrupted along the coast from northern Broward County through Palm Beach County. The heavily modified coastal habitat provided this species with the open sunny conditions and cement analogues to the rocky substratum to which it is adapted. Its ubiquity, rate of geographic expansion, combined with its carnivorous habits and large body size, have long since set the stage for an extensive restructuring of the indigenous and exotic lizard fauna in a way that has not been seen since its initial establishment in Palm Beach County almost one-half century ago. Urban heat island effects notwithstanding, frost isotherms predict instability of populations north of Fort Pierce and just below Sarasota on the West Coast.
\end{abstract}

\section{Introduction: Colonization History}

The Northern Curlytail Lizard, Leiocephalus carinatus armouri Gray, is primarily a medium-sized terrestrial lizard of open, rocky terrain, endemic to the islands of the Little Bahama Bank (Schwartz and Henderson 1991, Schwartz and Thomas 1975), and established along the southeastern Florida coastline (Meshaka et al. 2004; Smith and Engeman, 2003a, 2004b). It is also known from two separate sites in the southwestern Florida coastal counties of Collier (McCoid 2002) and Lee (Campbell and Klowden 2004). Its geographic expansion during a nearly one-half century presence in Florida has been exceptionally well-documented, which began with an intentional release of 20 pairs of the species on the island of Palm Beach during the 1940s (Weigl et al. 1969). This population then dispersed at least 20 city blocks (King 1960, Weigl et al. 1969), the boundaries of which were Royal Poinciana Way (north), Clarke Avenue (south), Atlantic Ocean (east), and the Intracoastal Waterway (west) (King 1960). By 1968, less than 30 years after its introduction, L. c. armouri was common from as far north as the Palm Beach Country Club, and as far south as South Ocean and Sea Grape Circles, a range extension of $3.21 \mathrm{~km}$ north

${ }^{1}$ The State Museum of Pennsylvania, 300 North Street, Harrisburg, PA $17120 .{ }^{2}$ Florida Department of Environmental Protection, Florida Park Service, 13798 S.E. Federal Highway, Hobe Sound, FL 33455. ${ }^{3}$ National Wildlife Research Center, 4101 LaPorte Avenue, Fort Collins, CO 80521-2154. ${ }^{4}$ Florida Department of Environmental Protection, Florida Park Service Student Intern Program, 13798 S.E. Federal Highway, Hobe Sound, FL 33455. ${ }^{5}$ Florida Atlantic University, Wilkes Honors College, 5353 Parkside Drive, Jupiter, FL 33458. *Corresponding author - wmeshaka@state.pa.us. 
and $5.63 \mathrm{~km}$ south (ca. $4.02 \mathrm{~km}^{2}$; Weigl et al. 1969). Weigl et al. (1969) also found a small population on the mainland at the base of the Flagler Bridge, where it touches West Palm Beach, and believed that L. c. armouri could extend its geographic range $2.85 \mathrm{~km}$ north to the Palm Beach Inlet and $12.2 \mathrm{~km}$ south to the Boynton Beach Inlet at the southern end of Palm Beach Island. By 1975, however, disjunct populations of this species were firmly established on the Florida mainland at the Flagler Bridge approach and near the Royal Palm Way Bridge approach (Callahan 1982). By 1981, L. c. armouri also was established on the mainland at the Southern Boulevard Bridge and Lake Avenue Bridge approaches (Callahan 1982). Most recently, Smith and Engeman (2003b) reported the species as abundant since 1986 at Woolbright Road and the Intracoastal Waterway (ICW), an additional $3.4 \mathrm{~km}$ farther south of the speculated southern limit (Weigl et al. 1969).

In the opposite direction, Leiocephalus carinatus armouri expanded northward into Martin County (Hauge and Butterfield 2000; Smith and Engeman 2002, 2003a, 2004a; Smith et al. 2004), and a recent survey during September 2002 documented a nearly contiguous $90 \mathrm{~km}$ Atlantic coastline south-north range from at least Lighthouse Point, Broward County, to Hobe Sound, Martin County (Smith et al. 2004). Callahan (1982) calculated the range expansion area of the Island of Palm Beach population from 19451981 as averaging $50.0 \mathrm{ha} / \mathrm{yr}$. $\left(0.5 \mathrm{~km}^{2} / \mathrm{yr}\right)$, and for the Palm Beach County mainland population from $1968-1981$ as $84.2 \mathrm{ha} / \mathrm{yr}$. $\left(0.842 \mathrm{~km}^{2} / \mathrm{yr}\right)$. Smith et al. (2004) reported an $80 \mathrm{~km}$ Atlantic coastline linear range expansion on the mainland: a calculation of about a $2.4 \mathrm{~km} / \mathrm{yr}$ average dispersal rate. Comparatively, this rate of linear range expansion was 2.4 times greater than the $0.98 \mathrm{~km} / \mathrm{yr}$ average rate of dispersal during the nine years from 1959 to 1968 (Smith et al. 2004, Weigl et al. 1969).

Our goal here is to extend the search for this species northward to Brevard County, its current northern range limit in Florida (Krysko and King 2002) and to, with presence and absence data from surveys, evaluate its status along the coast of Martin, St. Lucie, and Indian River Counties.

\section{Methods}

During 30 August-18 October 2003, we conducted coastal surveys for Leiocephalus carinatus armouri from the northern end of Martin County, as an extension of where a previous survey concluded (Smith et al. 2004), northward through St. Lucie and Indian River Counties. As per Smith et al. (2004), surveys were conducted during 0800-1000 hrs and 1300-1800 hrs on sunny days when we expected lizards to be visible above-ground. Voucher specimens were deposited at The State Museum of Pennsylvania in Harrisburg.

\section{Results and Discussion}

We found individuals in two of 40 sites from Martin (SMP-2108) and St. Lucie (SMP-2130) Counties, approximately $25 \mathrm{~km}$ apart from one another (Table 1, Fig. 1). No lizards were found in Indian River County. At both sites, lizards were predictably in association with stone and asphalt structures, yet 
found at no other structurally similar sites. The two sites with lizards were also apart from one another. We are unsure of the status of L. c. armouri in Martin County between the record of 2002 (Smith et al. 2004) and our 2003 record of the present study. However, the near absence of records north of our Martin County record lead us to conclude that the species has only tenuously colonized St. Lucie and Brevard counties. It is precisely these peripheral and disjunct populations that will provide the most accurate information regarding colonization dynamics, both in ability to persist and interspecific interactions.

A question derived from our findings is why, despite a historical presence in the region, ubiquity, and a recent increase in dispersal rate, Leiocephalus

Table 1. Survey locations for the Northern Curlytail Lizard (Leiocephalus carinatus armouri) in Florida.

\begin{tabular}{|c|c|c|c|}
\hline Street location & County & Latitude and longitude & $\begin{array}{c}\text { Specimens } \\
\text { observed } \\
\text { (adults/ } \\
\text { juveniles) }\end{array}$ \\
\hline Sebastian Inlet at A1A & Indian River & $\left(27^{\circ} 51.507^{\prime} \mathrm{N}, 80^{\circ} 26.862^{\prime} \mathrm{W}\right)$ & $0 / 0$ \\
\hline Roseland Road at US Hwy. 1 & Indian River & $\left(27^{\circ} 50.441^{\prime} \mathrm{N}, 80^{\circ} 29.220^{\prime} \mathrm{W}\right)$ & $0 / 0$ \\
\hline CR 512 at US Hwy. 1 & Indian River & $\left(27^{\circ} 48.536^{\prime} \mathrm{N}, 80^{\circ} 27.969^{\prime} \mathrm{W}\right)$ & $0 / 0$ \\
\hline Wabasso Road at A1A & Indian River & $\left(27^{\circ} 45.797^{\prime} \mathrm{N}, 80^{\circ} 23.821^{\prime} \mathrm{W}\right)$ & $0 / 0$ \\
\hline CR 510 at US Hwy. 1 & Indian River & $\left(27^{\circ} 44.914^{\prime} \mathrm{N}, 80^{\circ} 26.121^{\prime} \mathrm{W}\right)$ & $0 / 0$ \\
\hline $69^{\text {th }}$ Street at US Hwy. 1 & Indian River & $\left(27^{\circ} 43.144^{\prime} \mathrm{N}, 80^{\circ} 25.250^{\prime} \mathrm{W}\right)$ & $0 / 0$ \\
\hline Ronald Miller Drive at A1A & Indian River & $\left(27^{\circ} 41.690^{\prime} \mathrm{N}, 80^{\circ} 22.312^{\prime} \mathrm{W}\right)$ & $0 / 0$ \\
\hline $45^{\text {th }}$ Street at US Hwy. 1 & Indian River & $\left(27^{\circ} 40.485^{\prime} \mathrm{N}, 80^{\circ} 24.445^{\prime} \mathrm{W}\right)$ & $0 / 0$ \\
\hline Beachland Blvd at A1A & Indian River & $\left(27^{\circ} 39.202^{\prime} \mathrm{N}, 80^{\circ} 21.634^{\prime} \mathrm{W}\right)$ & $0 / 0$ \\
\hline Aviation Blvd. at US Hwy. 1 & Indian River & $\left(27^{\circ} 39.095^{\prime} \mathrm{N}, 80^{\circ} 24.055^{\prime} \mathrm{W}\right)$ & $0 / 0$ \\
\hline $21^{\text {st }}$ Street at US Hwy. 1 & Indian River & $\left(27^{\circ} 38.395^{\prime} \mathrm{N}, 80^{\circ} 23.366^{\prime} \mathrm{W}\right)$ & $0 / 0$ \\
\hline $8^{\text {th }}$ Street at US Hwy. 1 & Indian River & $\left(27^{\circ} 36.958^{\prime} \mathrm{N}, 80^{\circ} 23.265^{\prime} \mathrm{W}\right)$ & $0 / 0$ \\
\hline Oslo Road at US Hwy. 1 & Indian River & $\left(27^{\circ} 35.213^{\prime} \mathrm{N}, 80^{\circ} 22.662^{\prime} \mathrm{W}\right)$ & $0 / 0$ \\
\hline Highland Drive at US Hwy. 1 & Indian River & $\left(27^{\circ} 33.943^{\prime} \mathrm{N}, 80^{\circ} 22.210^{\prime} \mathrm{W}\right)$ & $0 / 0$ \\
\hline Avalon State Park at A1A & Indian River & $\left(27^{\circ} 32.286^{\prime} \mathrm{N}, 80^{\circ} 18.950^{\prime} \mathrm{W}\right)$ & $0 / 0$ \\
\hline Indrio Road at US Hwy. 1 & St. Lucie & $\left(27^{\circ} 31.247^{\prime} \mathrm{N}, 80^{\circ} 21.363^{\prime} \mathrm{W}\right)$ & $0 / 0$ \\
\hline Ft Pierce Inlet State Park & St. Lucie & $\left(27^{\circ} 28.361^{\prime} \mathrm{N}, 80^{\circ} 17.683^{\prime} \mathrm{W}\right)$ & $0 / 0$ \\
\hline SR A1A at US Hwy. 1 & St. Lucie & $\left(27^{\circ} 28.218^{\prime} \mathrm{N}, 80^{\circ} 20.025^{\prime} \mathrm{W}\right)$ & $0 / 0$ \\
\hline Binney Drive at A1A & St. Lucie & $\left(27^{\circ} 27.913^{\prime} \mathrm{N}, 80^{\circ} 18.160^{\prime} \mathrm{W}\right)$ & $0 / 0$ \\
\hline Orange Avenue at US Hwy. 1 & St. Lucie & $\left(27^{\circ} 26.815^{\prime} \mathrm{N}, 80^{\circ} 19.552^{\prime} \mathrm{W}\right)$ & $0 / 0$ \\
\hline Ohio Avenue at US Hwy. 1 & St. Lucie & $\left(27^{\circ} 25.953^{\prime} \mathrm{N}, 80^{\circ} 19.562^{\prime} \mathrm{W}\right)$ & $0 / 0$ \\
\hline Emil Drive at US Hwy. 1 & St. Lucie & $\left(27^{\circ} 24.744^{\prime} \mathrm{N}, 80^{\circ} 19.565^{\prime} \mathrm{W}\right)$ & $0 / 0$ \\
\hline Farmers Market at US Hwy. 1 & St. Lucie & $\left(27^{\circ} 23.798^{\prime} \mathrm{N}, 80^{\circ} 19.565^{\prime} \mathrm{W}\right)$ & $0 / 0$ \\
\hline Midway Road at US Hwy. 1 & St. Lucie & $\left(27^{\circ} 22.466^{\prime} \mathrm{N}, 80^{\circ} 19.564^{\prime} \mathrm{W}\right)$ & $0 / 0$ \\
\hline Prima Vista Blvd. at US Hwy. 1 & St. Lucie & $\left(27^{\circ} 19.601^{\prime} \mathrm{N}, 80^{\circ} 19.369^{\prime} \mathrm{W}\right)$ & $1 / 0$ \\
\hline Midport/Walton Road at US Hwy. 1 & St. Lucie & $\left(27^{\circ} 17.903^{\prime} \mathrm{N}, 80^{\circ} 18.236^{\prime} \mathrm{W}\right)$ & $0 / 0$ \\
\hline Jennings Road at US Hwy. 1 & St. Lucie & $\left(27^{\circ} 16.717^{\prime} \mathrm{N}, 80^{\circ} 17.530^{\prime} \mathrm{W}\right)$ & $0 / 0$ \\
\hline Port St. Lucie Blvd. at US Hwy. 1 & St. Lucie & $\left(27^{\circ} 16.240^{\prime} \mathrm{N}, 80^{\circ} 17.276^{\prime} \mathrm{W}\right)$ & $0 / 0$ \\
\hline SR 732 at $\mathrm{A} 1 \mathrm{~A}$ & Martin & $\left(27^{\circ} 15.423^{\prime} \mathrm{N}, 80^{\circ} 11.924^{\prime} \mathrm{W}\right)$ & $0 / 0$ \\
\hline Jensen Beach Road at US Hwy. 1 & Martin & $\left(27^{\circ} 14.717^{\prime} \mathrm{N}, 80^{\circ} 16.326^{\prime} \mathrm{W}\right)$ & $0 / 0$ \\
\hline Stuart Beach Park at A1A & Martin & $\left(27^{\circ} 12.944^{\prime} \mathrm{N}, 80^{\circ} 10.564^{\prime} \mathrm{W}\right)$ & $0 / 0$ \\
\hline Stuart City Hall SW Flagler Ave. & Martin & $\left(27^{\circ} 12.035^{\prime} \mathrm{N}, 80^{\circ} 15.270^{\prime} \mathrm{W}\right)$ & $0 / 0$ \\
\hline Kanner Hwy at US Hwy. 1 & Martin & $\left(27^{\circ} 11.468^{\prime} \mathrm{N}, 80^{\circ} 15.206^{\prime} \mathrm{W}\right)$ & $0 / 0$ \\
\hline Cutoff Road at A1A & Martin & $\left(27^{\circ} 11.366^{\prime} \mathrm{N}, 80^{\circ} 14.710^{\prime} \mathrm{W}\right)$ & $0 / 0$ \\
\hline Monterey Road at US Hwy. 1 & Martin & $\left(27^{\circ} 10.625^{\prime} \mathrm{N}, 80^{\circ} 14.225^{\prime} \mathrm{W}\right)$ & $0 / 0$ \\
\hline Airport Road at A1A & Martin & $\left(27^{\circ} 10.466^{\prime} \mathrm{N}, 80^{\circ} 13.743^{\prime} \mathrm{W}\right)$ & $0 / 0$ \\
\hline Indian Street at US Hwy. 1 & Martin & $\left(27^{\circ} 09.946^{\prime} \mathrm{N}, 80^{\circ} 13.650^{\prime} \mathrm{W}\right)$ & $0 / 0$ \\
\hline Salerno Road at A1A & Martin & $\left(27^{\circ} 08.783^{\prime} \mathrm{N}, 80^{\circ} 11.834^{\prime} \mathrm{W}\right)$ & $3 / 6$ \\
\hline Salerno Road at US Hwy. 1 & Martin & $\left(27^{\circ} 08.428^{\prime} \mathrm{N}, 80^{\circ} 12.656^{\prime} \mathrm{W}\right)$ & $0 / 0$ \\
\hline Cove Road at US Hwy. 1 & Martin & $\left(27^{\circ} 08.043^{\prime} \mathrm{N}, 80^{\circ} 12.405^{\prime} \mathrm{W}\right)$ & $0 / 0$ \\
\hline
\end{tabular}


carinatus armouri is only spotty in its distribution north and south of Palm Beach County? Rocky, well-drained substratum with which this species is associated extends northward through Flagler County, with the Anastasia formation of limestone, sand, and clay, and southward to the Florida Keys, with Miami oolite and Key Largo limestone (Brown et al. 1991). Furthermore, the coastal climate is frost-free southward through the Keys, yet distribution of L. c. armouri in Broward County is not reported as continuous, and its presence in Florida City (Miami-Dade County) is recent (Meshaka et al. 2004). Extensive searching, especially in Broward County, will determine if the observed discontinuous distribution pattern south of Palm Beach County is real or apparent. Its distributional pattern north of Palm Beach County, however, is another matter. The mean date of first $0^{\circ} \mathrm{C}$ frost occurring along the coast north of West Palm Beach ranges from less than 50\% occurrence to 20 January midway through Indian River County (Bradley 1975). The likelihood of a last frost is less than 50\% south of Ft. Pierce in northern St. Lucie County (Bradley 1975). From these frost predictions, we contend that the expected geographic range of this West Indian species on Florida's East Coast is secure only through extreme southern St. Lucie County, much less certain through Ft. Pierce, perhaps reinforced even ephemerally by motor vehiclefacilitated dispersal from southerly populations (Smith and Engeman 2003a). The historic and present day geographic distribution of L. c. armouri corroborates this prediction. We qualify our findings with the somewhat stochastic pattern to human-mediated landscape changes (see Smith et al. 2004). The

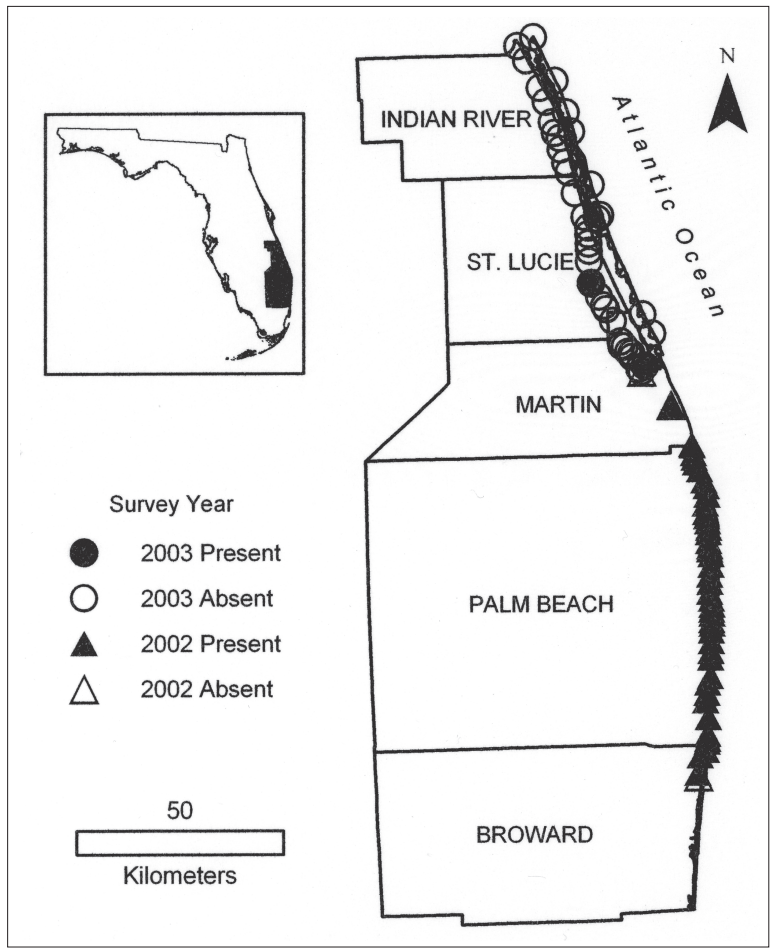

Figure 1. Distributional survey of the Northern Curlytail Lizard (Leiocephalus carinatus armouri) during 2002 (Smith et al. 2004) and 2003 (this study). See Table 1 for exact locations. 
future human-mediated range of L. c. armouri through habitat alteration, if to its liking, and frost moderation through urban heat islands, could easily extend past the expected range and appear first in such places as Melbourne, or perhaps even Titusville, through human-mediated dispersal-a phenomenon documented in other successful colonizing subtropical species in Florida and possible in this species as well (Godley et al. 1981, Hauge and Butterfield 2000, Meshaka 1996, Smith and Engeman 2003a). In this connection, the Brevard (Krysko and King 2000) County colony appears to be such a site. On the west coast of Florida, freeze probabilities (Bradley 1977) predict continuous distribution northward until just below Sarasota.

Our primary concern associated with its range expansion is its depredations, and this topic has received some attention. Callahan (1982) reported "from 60 to 30 percent fewer brown anoles per transect were in evidence at sites where L. c. armouri were active." Callahan (1982) concluded that "the brown anole (Anolis sagrei), has undergone a population reduction in areas where L.c. armouri have become established. Anolis sagrei has apparently shifted its activity to more arboreal portions of the habitat." The degree if at all to which $A$. sagrei Duméril and Bibron is being outcompeted is unknown; however, saurophagy is a part of the ecology of L. c. armouri (Dean et al., in press; Smith and Engeman 2003a, 2004b). Quite possibly, dense populations of A. sagrei could provide geographically expanding populations of L. c. armouri with a nutritious prey base to its advantage, much the same way native hylid species provide the invading Cuban Treefrog, Osteopilus septentrionalis Duméril and Bibron with a nutritious food source and simultaneously with a reduction in potential competitors (Meshaka 2001). As a potential replacement and displacer of A. sagrei (Callahan 1982, Schoener et al. 2002), the indigenous lizard fauna with which L.c. armouri occurs, or will occur, are most certainly at risk. In this regard, the combined study ranges of Callahan (1982) and that of Smith et al. (2004) are within the geographic range of the Green Anole, A. carolinensis Voigt; Six-lined Racerunner, Cnemidophorus sexlineatus sexlineatus Linnaeus; Southeastern Five-lined Skink, Eumeces inexpectatus Taylor; and, in some places, the Florida Scrub Lizard, Sceloporus woodi Stejneger. Consequently, it is reasonable to speculate that native lizards have been, or will be, impacted in some fashion by L. c. armouri within its expanding Florida coastal peninsula and barrier island range, more so in the least humandisturbed habitats than in urban areas; a topic yet to be examined in Florida populations of this species.

\section{Acknowledgments}

We acknowledge the professional kindness of the staff of the State Museum of Pennsylvania in Harrisburg, PA, in association with the use of that facility as a repository for the specimens of this study.

\section{Literature Cited}

Bradley, J.T. 1975. Freeze probabilities in Florida. Bulletin 777. Institute of Food and Agricultural Sciences. University of Florida, Gainesville, FL. 
Brown, R.B., E.L. Stone, and V.W. Carlisle. 1991. Soils. Pp. 35-69, In R.L. Myers and J.J. Ewel (Eds.). Ecosytems of Florida. University of Central Florida Press. Orlando, FL. 765 pp.

Callahan, R.J. 1982. Geographical and ecological distribution of the lizard Leiocephalus carinatus armouri in South Florida. Unpublished M.A. Thesis. University of South Florida, Tampa, FL. 70 pp.

Campbell, T.S., and G.S. Klowden. 2004. Leiocephalus carinatus (Northern Curlytailed Lizard). Herpetological Review 34:384.

Dean, C.L., R.M. Engeman, H.T. Smith, and W.E. Meshaka, Jr. In press. Leiocephalus carinatus armouri (Northern Curly-tailed Lizard): Cannibalism. Herpetological Review.

Godley, J.S., F.E. Lohrer, J.N. Layne, and J. Rossii. 1981. Distributional status of a lizard in Florida: Anolis sagrei. Herpetological Review 12:84-86.

Hauge, J.B., and B.P. Butterfield. 2000. Leiocephalus carinatus armouri (Northern Curlytail Lizard), USA: Florida: Martin Co. Herpetological Review 31:53.

King, F.W. 1960. New populations of West Indian reptiles and amphibians in southeastern Florida. Quarterly Journal Florida Academy of Sciences 23:71-73.

Krysko, K.L., and F.W. King. 2002. Leiocephalus carinatus armouri (Little Bahama Curly-tailed Lizard), USA: Florida: Brevard Co. Herpetological Review 33:148.

McCoid, M.J. 2002. Leiocephalus carinatus (Curly-tailed Lizard), USA: Florida: Collier Co. Herpetological Review 33:322.

Meshaka, Jr., W.E. 1996. Vagility and the Florida distribution of the Cuban Treefrog (Osteopilus septentrionalis). Herpetological Review 27:37-40.

Meshaka, Jr., W.E. 2001. The Cuban Treefrog in Florida: Life History of a Successful Colonizing Species. University Press of Florida. Gainesville, FL. 191 pp.

Meshaka, Jr., W.E., B.P. Butterfield, and J.B. Hauge. 2004. The Exotic Amphibians and Reptiles of Florida. Krieger Publishing Company, Malabar, FL. 166 pp.

Schoener, T.W., D.A. Spiller, and J.B. Losos. 2002. Predation of a common Anolis lizard: Can the food-web effects of a devastating predator be reversed? Ecological Monographs 72:383-407.

Schwartz, A., and R.W. Henderson. 1991. Amphibians and Reptiles of the West Indies: Descriptions, Distributions, and Natural History. University of Florida Press, Gainesville, FL. 720 pp.

Schwartz, A., and R. Thomas. 1975. A checklist of West Indian amphibians and reptiles. Carnegie Museum of Natural History Special Publication 1:127-129.

Smith, H.T., and R.M. Engeman. 2002. An earlier report of the exotic Northern Curlytailed Lizard in Martin County, Florida. Florida Field Naturalist 30:132-133.

Smith, H.T., and R.M. Engeman. 2003a. A review of the range, distribution, and ecology of the invasive Northern Curly-tailed Lizard in Florida. Florida Park Service Technical Report. Hobe Sound, FL. 5 pp.

Smith, H.T., and R.M. Engeman. 2003b. Leiocephalus carinatus armouri (Northern Curly-tailed Lizard). Opportunistic predation. Herpetological Review 34:245-246.

Smith, H.T., and R.M. Engeman. 2004a. Leiocephalus carinatus armouri (Northern Curly-tailed Lizard). Predation. Herpetological Review 35:169-170.

Smith, H.T., and R.M. Engeman. 2004b. A review of the colonization dynamics of the Northern Curly-tailed Lizard (Leiocephalus carinatus armouri) in Florida. Florida Field Naturalist 32:107-113.

Smith, M.M., H.T. Smith, and R.M. Engeman. 2004. Extensive contiguous northsouth range expansion of the original population of an invasive lizard in Florida. International Biodeterioration and Biodegradation 54:261-264.

Weigl, G.L., R.G. Domey, and W.R. Courtenay, Jr. 1969. Survival and range expansion of the Curly-tailed Lizard, Leiocephalus carinatus armouri, in Florida. Copeia 1969:841-842. 